\title{
Itinéraires Itinéraires
}

Littérature, textes, cultures

2010-3 | 2010

Médiévalisme

\section{Comic Books Featuring the Middle Ages}

\section{Mónica Ann Walker Vadillo}

\section{OpenEdition}

\section{Journals}

Electronic version

URL: http://journals.openedition.org/itineraires/1877

DOI: 10.4000/itineraires. 1877

ISSN: 2427-920X

\section{Publisher}

Pléiade

\section{Printed version}

Date of publication: 1 November 2010

Number of pages: 153-163

ISBN: 978-2-296-13150-7

ISSN: $2100-1340$

Electronic reference

Mónica Ann Walker Vadillo, " Comic Books Featuring the Middle Ages », Itinéraires [Online], 2010-3 | 2010, Online since 01 November 2010, connection on 30 April 2019. URL : http:// journals.openedition.org/itineraires/1877 ; DOI : 10.4000/itineraires.1877

\section{(c) (1) $\Theta$}

Itinéraires est mis à disposition selon les termes de la licence Creative Commons Attribution - Pas d'Utilisation Commerciale - Pas de Modification 4.0 International. 


\title{
Comic Books Featuring the Middle Ages
}

\begin{abstract}
This article explores comic books that feature the Middle Ages as a way to show how the study of this popular media can help to further the research of the modernity of the Middle Ages. Comic books feature the Middle Ages in two different ways : on the one hand, some comic books are inspired by historical sources and characters, and on the other hand, some comic books are inspired by literary sources whose origin can be traced to the Middle Ages. Both of them have created a rich but often distorted idea of the Middle Ages.
\end{abstract}

Keywords: comic books, Middle Ages, chivalry, King Arthur, Robin Hood, Melusine

Mots clés : bandes dessinées, Moyen Âge, chevalerie, roi Arthur, Robin Hood, Mélusine

\section{Introducing Comic Books Featuring the Middle Ages}

If the concept of the Middle Ages have fluctuated since the Renaissance, the form and content of comic books have also fluctuated until they attained the form, for which they are now known, in the nineteenth century ${ }^{1}$. Since then the comics have constituted a genuine sociological and cultural phenomenon that have already spanned over more than a century with an ever increasing popularity and a wide range of audiences of all ages and social backgrounds.

This paper explores the medievalism of comic books taking into consideration the cultural and historical background of their creation and the type of concepts that they borrowed from the medieval period. In addition, I will try to demonstrate how an inquiry into this aspect of

1. Gérard Blanchard, Histoire de la bande dessinée : une histoire des histoires en images de la préhistoire à nos jours, Verviers, Marabout, 1974, p. 84. 
popular culture could open up a venue for the study of the modernity of the Middle Ages. Taking into consideration the number and the diverse nature of the examples of comic books that deal with some aspect of the Middle Ages, the paper will not follow a strictly chronological framework. Instead, the focus will be centered on the different features that were taken from the Middle Ages. Some of these aspects come from historical, mythological, and literary sources. In addition, many comic books make direct visual references to standing monuments or images from the Middle Ages. The first part of the paper will explore the historical and mythological aspects that were borrowed from the Middle Ages for the creation of these comic books; and the second part of the paper will deal with the appropriation and transformation of literary sources of the Middle Ages, followed by some preliminary remarks on the use of comic books to study the modernity of the Middle Ages.

\section{Comic books and Historical Sources from the Middle Ages}

Comic books dealing with the Middle Ages present a mythological or archetypical vision of this time period. Even though, they do not give a historical view, for their creation they demand some knowledge of the history which they depict. Several, if not, all of the creators of the medievalthemed comics have commented on the origin of their ideas based on their love and interest on the history of the Middle Ages. Some of their interests rely on the historical and mythological aspects related to feudalism, knighthood or the chivalric code, and other times they seek inspiration in historical figures such as the Vikings or Richard the Lionheart, as we will see in the following examples. It is important to point out that many of these ideas and motives will repeat themselves in comic books that have medieval literary sources.

In 1985, Chris Claremont and John Bolton, two of Britain's great comic book creators, collaborated in a graphic novel entitled The Black Dragon $^{2}$. Demonstrating a great knowledge of the folklore and mythology of the British Isles, The Black Dragon creates a story of intrigue around the time when Christianity began displacing the original religions of the Isles. The story takes place in 1193, right after the death of Henry II, before the return of Richard the Lionheart to reclaim the throne, and is set against the background of the struggles and rivalries between the Normans and the Saxons. This is the England that we know from Walter Scott's Ivanhoe. In addition, this potentially historical background is enriched by the inclusion of Celtic folklore with druids, fairies, avatars, and mystical places which makes this graphic novel into a medieval fantasy epic. The comic book narrates the adventures of James Dunreith, Duke of Ca'rynth, whose true

2. Chris Claremont and John Bolton, The Black Dragon, Barcelona, World Comics-Planeta de Agostini, 1996 (Spanish version). 
nature - unknown to him - was that of the Black Dragon that protects the Land and all of its inhabitants, magical and human alike. After living in exile for a long time, James returns to England after hearing the news of the death of his king and lord Henry II. On his arrival, he is detained and brought to the presence of queen Eleanor of Aquitane. She entrust him with the mission of spying upon an old friend who is said to deal in black magic. Throughout the story, represented very realistically in strictly black and white tones, the feudal world is represented in all its ugliness and splendour. James Dunreith is a vassal of Henry II, and as such he has certain legal and military obligations that bound him to the king. He demonstrates his courage and loyalty as a knight, but also as a defender of the weak and as a devoted admirer of the lady Ellianne DeValere, the daughter of his friend and possible traitor. James embodies all the characteristics of knighthood as he upholds the chivalric code. In this construction of the British Isles in the twelfth century, it is possible to see the rise of the knight, a member of the warrior class, acquiring the characteristics of the gentle nobleman. When the characters resort to fighting they do it for a cause that they deem just, like in the crusades or in royal service, as a game in a tournament, or fighting the evil forces that want to destroy their way of life.

All these elements, feudalism, knighthood, or chivalry, also appear in other French comic books such as Le Coeur de Lion created by JeanChristophe Vergne who retraces the history of the British monarch ${ }^{3}$ in a rather well-thought and researched biography of Richard where he has to navigate through the crusades and the treachery and villainy of this brother, Prince John, proving constantly his reputation as a great military leader and warrior. Another outstanding comic book dealing with these same issues is the trilogy created in 1984 by François Bourgeon called Les Compagnons du Crépuscule ${ }^{4}$. The narrative of this comic book is set against the background of the Hundred Years' War in France during the fourteenth century, and, as in the previous example, Bourgeon did extensive research on the history of France to create an accurate vision of the Late Medieval Period.

In Spain these concepts are also present in works such as Captain Thunder created in 1956 by Víctor Mora Pujadas and Ambrós ${ }^{5}$ or in El Cid created by Ángel Hernández Palacios in $1971^{6}$. In Captain Thunder Víctor Mora and Ambrós tell the story of the son of a Spanish feudal lord in northern Catalonia, who in the last quarter of the twelfth century, gives

3. Jean-Christophe Vergne, Le Cæur de Lion, 1. Fils d'Alienor, Saint-Martin-du-Bec, AssorBD, 2001.

4. François Bourgeon, Les Compagnons du Crépuscule, Tournai, Casterman, t. I, 1984; t. II, 1986; t. III, 1990.

5. John M. Burns and Víctor Mora, Cómo nació El Capitán Trueno - La reina bruja de Anubis, Barcelona, Ediciones B, 1991.

6. Antonio Hernández Palacios, El Cid, Vitoria-Gasteiz, Álava, Ikusager Ediciones, 1982. 
his title and lands to his younger brother after being dubbed a knight. $\mathrm{He}$ leaves the country to fight in the crusades where he and his friends join the forces of Richard the Lionheart in 1191. He is an adventurer who seeks to find a way to demonstrate his courage and his condition as defender of the weak, the oppressed and, above everything else, of justice. Once again the ideals of knighthood and chivalry are again emphasized in the figure of a Spanish knight. In El Cid, Hernández Palacios takes the young Rodrigo Díaz de Vivar and places him against the historical background of medieval Spain in the eleventh century. El Cid also describes visually several aspects of medieval warfare and politics in the Iberian Peninsula with such realistic appeal that it continues to be one of the best historical comic books ever created in Spain.

Not only are concepts and historical figures from the Middle Ages represented in comic books, but also a whole population : the Vikings. No other people have created such great interest than these explorers, warriors, merchants, and pirates from Scandinavia that raided and colonized large areas of Europe from the late eighth to the early eleventh centuries ${ }^{7}$. These Norsemen used their long ships, known as drakars, to travel from the coast of Scandinavia to Constantinople, Russia, France, England or Iceland, terrorizing their inhabitants. The Vikings, like the Middle Ages, have also gone through a conceptual change when their image was romanticized in the eighteenth century as the Germanic noble savages ${ }^{8}$. In contemporary popular culture the Vikings have been depicted with ever increasing exaggerated clichés that present them almost in a caricature way. Such is the case in Hägar the Horrible, one of the most beloved syndicated cartoons since it appeared in 1973 by the hand of the cartoonist Dick Browne ${ }^{9}$. Browne created Hägar reflecting back on some Old Norse Legends that his Swedish aunt had told him when he was a child ${ }^{10}$. He began to sketch out a horned Viking helmet sitting on top of a big round nose, and hence Hägar was born. This marauder then was accompanied by his clan. A strong-willed warrior woman named Helga became his wife; Hamlet was the name given to their younger and studious son who would become an embarrassment to his slovenly and illiterate father; and Honi became the name of their beautiful older daughter who wanted to fight like his father in a suit of armour similar to the one worn by Wagner's valkyries. Most of the comic strips revolve around family issues, but also present are assaults to castles, trips to sack villages in Ireland and Scotland, constant fighting and seafaring. All these elements present

7. Else Roesdahl, The Vikings, London, Penguin, 1998.

8. Johnni Langer, « The origins of the imaginary Viking », Viking Heritage Magazine, Visby (Sweden), Gotland University/Centre for Baltic Studies, no. 4, 2002.

9. Dick Browne, Hägar the Horrible : The Epic Chronicles, Dailies 1973 to 1974, London, Titan Books, 2009.

10. Ibid., p. 3. 
the Vikings in a very humorous and enchanting way. In similar lines the cartoonist Gary Larson has also created a number of single-panel comic strips with the Vikings as the main subject in his acclaimed creation The Far Side ${ }^{11}$. In these panels, the Vikings also wear horned headdresses, sack villages, and return home from the siege of a castle. Nevertheless, there are also more serious comic books dealing with the Vikings such as the series Northlanders created by Brian Wood in $2007^{12}$. Even though the characters are fictional, it is set around historical events in the Viking Age. Wood said that the series was going to be divided into standalone eight issue story lines separated by a different two-issue story line ${ }^{13}$. In the first story line, «Sven the Returned », Sven, the main character, is a self-exiled Viking warrior serving in the Byzantine Varangian Guard, who returns in 980 to his birth region in the Orkney Islands in order to reclaim his rightful inheritance. The second story line, "Lindisfarne", deals with a young boy and the sacking of the Lindisfarne monastery in 793 A.D., which opens the Viking Age. The third story line, « The Cross + the Hammer », is set around Dublin, Ireland, circa 1014 during the Battle of Clontarf, and follows the chase of an Irishman who attacks the occupying Viking forces using guerrilla tactics. As with many other comic book writers, Brian Wood did extensive research on the historical Vikings to present a realistic and believable setting. The same is true, although with a twist, of the new series Viking created by Ivan Brandon and illustrated by Nick Klein in $2009^{14}$. In this new comic book, Brandon approaches the familiar Norsemen archetype in terms of a modern crime organization following the exploits of two brothers that try to rise in the ranks of the criminal underworld ${ }^{15}$. Brandon mentioned that he was inspired for the project after reading a book about Viking history and he considered the parallels that it had with modern organized crime ${ }^{16}$.

These comic books based on historical sources have created a continuous rediscovery of the Middle Ages with every new issue sold in stores. This rediscovery cannot be considered to represent an accurate description of the time period. It is a conceptual construct that can be use or abused depending on the creator of the comic book. This construction with the representation or misrepresentation of a reality that is far away

11. Gary Larson and Steve Martin, The Complete Far Side 1980-1994 (2 vols.), Kansas City, Andrews McMeel Publishing, 2003.

12. Brian Wood and Massimo Cavernale, Northlanders \#1, New York, Vertigo, 2007.

13. «Northlanders », in Wikipedia (http://en.wikipedia.org/wiki/Northlanders), consulted November $10^{\text {th }}, 2009$.

14. Ivan Brandon and Nick Klein, Viking \#1, Berkeley, Image Comics, 2009.

15. Michael Patrick Sullivan, «Ivan Brandon Conquers Image with Viking », in CBR News (http://www.comicbookresources.com/?page=article\&id=20172), consulted November $10^{\text {th }}$, 2009.

16. Ibid. 
removed from our times continues to influence our understanding of the period and to perpetuate the myths that have been created around it. As Dominique Barthélemy has pointed out in his article « Modern Mythologies of Medieval Chivalry », some of the concepts surrounding knighthood and chivalry are inventions that have little to do with the medieval world ${ }^{17}$. According to him, the dreams and myths surrounding knighthood have become a barrier to understanding the social classes and collective behavior of the past. In fact, knighthood never had « a single model of conduct : tournaments were disapproved by the Church, crusading was no game, and when men defended their honor and their class-interest, they didn't always succeed in bringing about the rule of justice ${ }^{18}$ ». Therefore, comics such as The Black Dragon, Richard the Lionheart, or Captain Thunder, are perpetuating an image of the noble knight that is not historical despite the obvious attempts of their creators to make it appear as close to the medieval reality as possible. The same can be said of the Vikings. « No self-respecting Viking ever wore a horned helmet. They weren't that dumb ${ }^{19}$. " Apart from two or three representations of ritual helmets, which had protrusions that may be either stylized ravens or snakes, no depiction of Viking Age warriors' helmets, and definitely no preserved ones, have horns ${ }^{20}$. This misconception was created in the nineteenth century by the Swedish Gothic League in order to foster the nationalistic movement. As long as the creators of comic books continue to find inspiration in the works created in the nineteenth century like those of Sir Walter Scott, the Pre-Raphaelites, or even twentieth century cinema, they will continue to perpetuate the distortions of earlier periods. Even when the comic book creators claim that they found inspiration in actual history books, like Viking by Brando, they twist the medieval in the service of their own interest.

\section{Comic Books and Literary Sources from the Middle Ages}

If the historical sources have created a myriad of comic books, several literary sources from the Middle Ages have become so popular that the artistic, literary and film industry contain an almost incommensurable amount of examples. Over the centuries, these medieval characters have passed through the hands of many storytellers and each has twisted, pushed and moulded the myth to their own taste and time period. To name all of

17. Dominique Barthélemy, « Modern Mythologies of Medieval Chivalry », in Peter Linehan and Janet L. Nelson (eds.), The Medieval World, London, Routledge, 2001, p. 214.

18. Ibid.

19. The Straight Dope Science Advisory Board, « Did Vikings Really Wore Horns on Their Helmets? », in The Straight Dope (http://www.straightdope.com/columns/read/2189/didvikings-really-wear-horns-on-their-helmets), consulted July $5^{\text {th }}, 2010$.

20. Johnni Langer, "The origins of the imaginary Viking ", Viking Heritage Magazine, Visby, Gotland University/Centre for Baltic Studies, no. 4, 2002. 
them would be to go beyond the scope of this article. In this part I would like to concentrate in the comic books that have as their main character King Arthur, Robin Hood, and Mélusine.

If someone tries to trace the trajectory of the story of King Arthur to its origins, the name of Geoffrey of Monmouth with his History of the Kings of Britain written in 1136 would be the first to be mentioned ${ }^{21}$. The main elements of the story already appear there with Utter Pendragon, Merlin, Excalibur, Tintagel, Mordred and Avalon, although they were later on expanded by Chrétien de Troyes with the addition of Lancelot and the Holy Grail, and Sir Thomas Malory with La Morte Darthur. These Arthurian romances became very popular during the Middle Ages, but they were soon forgotten during the following centuries until in the nineteenth century they experienced a major resurgence that have not diminished even after the turn of the twenty-first century ${ }^{22}$. According to Valerie Lagorio, the survival of the Arthurian myth has been connected with its sense of timelessness and its essential apocalyptic thrust ${ }^{23}$. Still the deep-rooted and universal fascination that this legend in particular holds even today is reflected in its diverse representations in comic books. It all started with Hal Foster in 1937 when thrilled by tales of chivalry, Foster returned to the rich literary tradition of King Arthur and the Knights of the Round Table and created Prince Valiant ${ }^{24}$. Considered by many as the best academic comic book ever created, Prince Valiant narrates the story of the heir to the throne of Thule (Norway) who in the company of King Arthur, Sir Gawain, and the rest of the Knights of the Round Table tries to reclaim his inheritance while he battles evil and injustice with the Singing Sword and upholding the chivalric code. This character was followed by The Black Knight created by Stan Lee and Joe Maneely in $1955^{25}$. Sir Percy of Scandia is a sixth century knight who serves at the court of King Arthur Pendragon as his greatest warrior and one of the Knights of the Round Table. He was recruited by the wizard Merlin who asked Percy to adopt a double identity. He then pretended to be totally incompetent until changing into the persona of the Black Knight who wields the Ebony Blade forged by Merlin himself from a meteorite.

21. Lewis Thorpe (ed.), Geoffrey of Monmouth, The History of the Kings of Britain, Harmondsworth, Penguin, 1966.

22. See Jennifer R. Goodman, The Legend of Arthur in British and American Literature, Boston, Twayne, 1988 and, in French, Anne Besson, Arthur au miroir du temps, Dinan, Terre de Brume, 2007.

23. Valerie M. Lagorio, « King Arthur and Camelot, U.S.A. in the Twentieth Century », in Bernard Rosenthal and Paul E. Szarmach (eds.), Medievalism in American Culture, Binghamton, New York, 1989, p. 151-169.

24. Gérard Blanchard, op. cit., p. 232.

25. Stan Lee and Joe Maneely, The Black Knight \#1, New York, Atlas Comics, 1955. 
In 1982 Mike W. Barr and Brian Bolland published a twelve-issue comic book called Camelot $3000^{26}$, which is said to continue the legends chronicled by Sir Thomas Malory. The series narrates the adventures of King Arthur, Merlin and the reincarnated Knights of the Round Table as they re-emerge in the year 3000 A.D. to fight off an alien invasion that was masterminded by Morgan Le Fay, Arthur's old nemesis. Fulfilling an ancient prophecy that he would return when England needs him most, Arthur is accidentally awakened from his resting place beneath Glastonbury Tor by Tom Prentice, a young archaeology student, whom Arthur makes first his squire and later on a knight. The two of them travel to Stonehenge, where Merlin lies trapped by the fairy creature Nyneve. They rescue him in order to help them retrieve Excalibur. Every major character in the story have been reincarnated, so Guinevere is reincarnated as an American military commander; Lancelot as a French philanthropist; Galahad as a Japanese samurai; Percival is a genetically altered monstrous giant; and Tristan is reincarnated as a woman. This last invention is the most original and gives a twist to the story. Tristan has to re-examine his previous conceptions regarding gender roles and he has to make his own peace with her sexuality after Isolde, the love of his life, appears ${ }^{27}$. The creator, Mike W. Barr was considered to be something of an expert on the Arthurian legends, but he admitted that all his knowledge came from a seminar that he had taken in college and other literary sources and he concluded,

\footnotetext{
in the writing of Camelot 3000, I took from the legends precisely what I could use.... and ignored or ruthlessly discarded that which I could not. My understanding of the Arthurian mythos, then, is that of perhaps more-thanusually-well-informed-layman, but no more ${ }^{28}$.
}

This expresses really well the way in which the legends of King Arthur were constructed by most of the comic book creators that have chosen to take on this character and the world that surrounds him.

Just like Arthur, Robin Hood has its origins in medieval literature. His name started to appear in the thirteenth century in songs and ballads and since then he has gone through many metamorphoses in concept and character ${ }^{29}$. In older versions Robin Hood was a commoner and an outlaw, but the most modern versions presents him as a dispossessed nobleman who was forced into the life of an outlaw, who fought the injustices of his

26. Mike W. Barr and Brian Bolland, Camelot 3000, New York, DC Comics, 1982-1985.

27. See Dominick Grace, "The Future King: Camelot 3000 », The Journal of Popular Culture, no. 41/1, 2008, p. 21-36.

28. Charles T. Wood, "Camelot 3000 and the Future of Arthur », in Martin B. Shichtman and James P. Carley (eds.), Culture and the King : The Social Implications of the Arthurian Legend, New York, State University of New York Press, 1994, p. 297-313.

29. Helen Phillips, Robin Hood : Medieval and Post-medieval, Cornell, Cornell University Press, 2003. 
society, and who happened to be an excellent archer ${ }^{30}$. In popular culture Robin Hood is typically seen as a contemporary and supporter of the late twelfth century king Richard the Lionheart. Robin was driven to outlawry during the misrule of Richard's evil brother Prince John while Richard was away in the Third Crusade. This view first gained currency in the sixteenth century ${ }^{31}$ and created a myth that has been perpetuated up until today. One of the first comic books of Robin Hood following this line was created in 1956 by Frank Bolle and it was entitled Robin Hood Tales ${ }^{32}$. This comic book often contained three or four small stories with back-up features about the Third Crusade and it included educational pages with titles such as « in the Days of Robin Hood» where they informed the public about medieval taxes, laws, and superstitions ${ }^{33}$. Throughout the years, there have been other one-issue comic books depicting this famous outlaw portraying him in a similar way than the Bolle comic books. Interesting enough in 1991, Michael Jan Friedman and Luke McDonnell created a series called Outlaws which was the re-imagining of the story set in a future time and against the background of a post-apocalyptic world ${ }^{34}$. Even the small format syndicated cartoon of the Wizard of Id, created by Brant Parker and Johnny Hart in 1964, features Robbing Hood, a forest-dweller who steals from the rich and gives to the poor. His first appearance in the strip involves a hold-up, at the conclusion of which his victim yells, "You dirty robbing hood! », hence the name ${ }^{35}$. The story of Robin Hood is still very much in vogue, this past summer saw the release of Outlaw : The Legend of Robin Hood by Tony Lee and Sam Hart. Furthermore, the superhero Green Arrow created in 1941 by Mort Weisdinger and George Papp (ongoing series up till today) can be considered a modern day Robin Hood. Even though there was no intention of casting Green Arrow as Robin Hood, the fact that the latter was a bowman, who had been socially displaced, and who was an iconoclastic questioner of authority made the comparison unavoidable, and soon many Robin Hood motifs began to inform everything about the character of the Green Arrow ${ }^{36}$.

30. Sarah Beach, « Robin Hood and Green Arrow : Outlaw Bowmen in the Modern Urban Landscape », in Thomas Hahn (ed.), Robin Hood in Popular Culture : Violence, Transgression, and Justice, Cambridge, D.S. Brewer, 2000, p. 21-28.

31. Richard B. Dobson and John Taylor, Rymes of Robyn Hood: An Introduction to the English Outlaw, Pittsburgh, Sutton Publishing, 1976, p. 5-16.

32. Frank Bolle, Robin Hood Tales \#1, Quality Comics, 1956.

33. Allen W. Wright, « Robin Hood Spotlight of the Month », in Robin Hood : Bold Outlaw of Barusdale and Sherwood (http://www.boldoutlaw.com/robspot/0199.html), consulted July $5^{\text {th }}, 2010$.

34. Michael Jan Friedman and Luke McDonnell, Outlaws \#1, New York, DC Comics, 1991.

35. Brant Parker and Johnny Hart, Wizard of ID, Panini, 2009.

36. Sarah Beach, op. cit., p. 24. 
Although one of the most popular characters from medieval literature that have had an innumerable amount of comic books devoted to him is Beowulf, I would like to focus on a different literary character : although she is not that well known, she proves that the Middle Ages can be a source of inspiration and creativity to modern comic book creators. Between 2000 and 2001 a two-volume comic book was produced in Poitiers by the hand of Didier Quella-Guyot and Sophie Balland. Mélusine, Fée Serpent ${ }^{37}$ is considered to be a historical and fairytale comic book. Mélusine is faithfully represented as she was described by Jean d'Arras in his Roman de Mélusine compiled around 1382-1393 ${ }^{38}$. The Count Raymond of Poitou encounters Mélusine in a forest in France, and enchanted by her beauty invites her to go with him and asks her to marry him. Mélusine accepts with one condition : that he should never attempt to enter her chamber on Saturdays. The count accepts her condition and they are very happy together - she bear the count many children, and erects for him a magnificent castle by her magical art. This marital harmony is uninterrupted until Raymond breaks his promise by concealing himself in order to behold his wife after his brother torments him with the worst possible gossip regarding Mélusine's faithfulness on Saturdays. He then discovers that his wife was half woman and half serpent. Hardly has Mélusine discovers the indiscreet intruder, than, transforming herself into a dragon, she departs with a loud yell of lamentation, and is never seen again. Still, she remains the protectress of her descendants, and is heard wailing as she sails over the castle of Lusignan the night before it is demolished. Even though the adaptation of the story in the comic book is free, it shows how Mélusine can be a touching hero, troublesome, and tragic and very contemporary. The comic book is set against the background of fourteenth century France and it uses original art work from the Middle Ages, from the façade of the cathedral of Poitiers to an actual miniature from the Très Riches Heures du Duc de Berry created by the Limbourg Brothers.

Regardless of their medieval origin, Arthur, Robin Hood, Beowulf and even Mélusine appear to have some sort of atemporal appeal. They have all become figures of myth and as such their stories represent the playing out of issues that are universally important for all human beings and not just of interest to a segment of the population. In many of these stories the hero belongs to the knightly class or, in the case of Robin Hood or Mélusine (albeit in different ways), climbs the social ladder and exhibits better morals than the upper class does. These heroic values are a testimony of the democratic era, and they are embodied in the chivalric code. In any case, the adventures of these heroes are in fact fictional exploits of

37. Didier Quella-Guyot and Sophie Balland, Mélusine, Fée Serpent, La Crèche, Geste, 2000-2001.

38. Jean d'Arras, Mélusine, London, Publisht [sic] for the Early English Text Society by Kegan Paul, Trench, Trübner, 1895. 
archetypes rather than actual adventures of historically defined individuals. As such they were taken by the comic book creators who placed them in a fictional and imaginary world that they envisioned as the Middle Ages. Through the retelling of these old myths, the comic book creators have influenced countless generations that have absorbed visually and in written form this « imagined » medieval world. The comic books of these legendary characters have transformed them into subjects of popular culture.

It appears that comic books have been able to bridge the distance between the historical Middle Ages and modern reconstructions of that period. Through the evocation of a time that was considered to be dark and superstitious, their heroes are exalted as the embodiment of the chivalric values such as loyalty, devotion to family, and physical courage. The representation of atemporal mythological figures such as King Arthur or Robin Hood demonstrates the appeal that still holds today of the heroic figures who are engaged in a struggle against overwhelming forces. The Middle Ages have, then, become a visual commodity of popular culture sold in comic book stores and as such they should be studied more extensively as examples of the modernity of the Middle Ages.

Mónica Ann Walker Vadillo Universidad Complutense de Madrid 